\title{
Identiteta, spoštovanje samega sebe in učljivost
}

Vsako leto doživljam s študenti trenutke, ko se nepričakovano zavedo, da je "vse relativno". Relativno je kognitivno področje, čustveno zorenje, relativno je oblikovanje samopodobe. V srednji šoli so jih varno vodili skozi labirinte znanja, čustvovanja in jim določali samopodobo. Drugi so prevzemali odgovornost zanje, za njihovo ǔenje, nemalokrat tudi za življenje. Drugi so jim povedali, kaj je prav, kaj ni prav in kaj je tisto najpomembnejše.

$\mathrm{Na}$ univerzitetnih predavanjih pa se študenti srečujejo z množico "referenčnih okvirjev", množico pogledov, vprašanj, $k i$ vodijo $v$ razmišljanje in iskanje odgovorov. Nenadoma spoznajo, da ne obstaja le eno znanje, da so znanja $v$ povezavi s temi referenčnimi okviri relativna. In če je vse tako relativno, potem si neizogibno zastavijo vprašanja "Kaj pa jaz sredi vsega? Kaj pa moje vrednote? Na čem lahko jaz gradim svojo trdnost ...? To so vprašanja tistega, ki oblikuje svoj jaz, išče svojo identiteto. Takšna vprašanja si postavljajo tudi odrasli ob življenjskih prelomnicah, v kriznih situacijah ali ob izobraževalnih vsebinah, ki jih navajajo na razmišljanje o njih samil. Če so vsa znanja in vrednote relativni, tedaj je človek izgubljen in prevzamejo ga čustva nelagodja. Več načinov je, da se šnuden "izvleče" iz tega stanja. Lahko se poda od konteksta do konteksta, da morda le odkrije zakonitosti, pomene, ki veljajo za več kot zgolj posamezno situacijo. Lahko se obnaša oportunistično, pri čemer situacijo izkoristi zase, za svoje dobro. Podredi se in opravi izpit. Tretja pot, ki se mu odpira in najbolj poveča učljivost, pa je pot dejavnega zavzemanja.

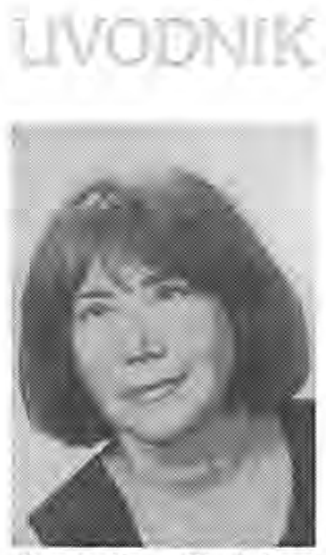

Dejavno zavzemanje pri študiju, delu, v družini, zavzenanje za neke vrednote. Nekdo, ki se za nekaj dejavno zavzema, se zaveda samega sebe.! In tedaj postane odgovoren za svoj razvoj, vpliva nanj, sam izbira sredi sveta, v katerem je use relativno. V tisto, kar izbere, vloži napor in zanos, Pri tem mora biti pogumen, odgovoren. Sprejeti mora dejstvo, da ne zmore vsega, da so tudi zmožnosti človeškega razuma omejene. Tedaj se zavzame za tisto, v kar resnično verjame. V tem primeru se spoštuje. Še več, ob tem spozna, da lahko prevzame odgovornost zase, pa tudi za druge. Odkrije, da je veliko stvari, ki jih je treba razumeti, se jih naučiti. Da lahko zagreši napake, pa tudi, da posamezne drobce celote obvlada, da lahko opravi neko delo, da ina cilje in vizijo. Spozna, da ne klone kar tako pod težo pritiskov, da se zmore odpreti za različna spoznanja in razmišljanja. Ko sprejme odločitev, ve, da jo sprejema sam in tudi sam prevzema njene posledice ${ }^{2}$.

Zdi se, da je človek najbolj učljiv, najbolj pripravljen na preobrazbo jaza prav takrat, ko išče odgovor na to, kdo je bil, kdo je in kdo lahko postane. Spominjam se udeleženke neke študijske skupine na temo medsebojnih odnosov, ki je čez. leto povedala, kako se je "potila", ko je po prvih študijskih srečanjih dobila uvid vase. Tedaj ni vedela, če bo zaradi teh silnih čustev pri učenju zdržala. Uvid vodi v čustveno zmedo, jezo, celo depresijo in posledično v preobrazbo jaza. Lahko rečemo, da čustva neizogibno določajo učljivost in so pomemben del procesa, ki ga imenujemo identiteta. Še več, če želite ugotoviti, kaj je identiteta nekega človeka, ga vprašajte, česa se boji, vprašajte ga, kaj ga jezi, kaj ima rad. 
Identiteta je namreč predvsem čustveni pa tudi kognitivni proces, v katerem človek sredi družbenega okolja $z$ delovanjem ustvarja razmeroma trajno predstavo o samem sebi. Ta predstava vpliva na učljivost. Če je pozitivna, ¿̌e zbuja več pozitivnih čustev, potem je vě̌ možnosti, da se učljivost poveča.

Imamo osebno in družbeno ali kolektivno identiteto. Slednjo črpamo iz pripadnosti skupinam, trajnim socialnim okoljem. Kaj se dogaja z našo osebno in družbeno identiteto zdaj, ko smo vse drugače mobilni, kot smo bili nekoč? Zdaj, ko razpada socialna mreža, ko je svet vse bolj brez ograj in utrjenih meja? .Je identiteta $v$ tem razdrobljenem svetu prav tako razdrobljena? Ali res ni ena sama, marveč skupek identitet? Se ob tem učljivost veča, ali pa nemara zaradi kognitivne, custvene, bivanjske zmede otrpnemo in se ne zmoremo učiti in spreminjati?

Vsekakor bi veljalo globlje preučiti vezi med dejavnostjo, čustvi, spoznanji ter osebno in družbeno identiteto, nastajajočo s pomočjo zunanjih vplivov, posrednikov, nosilcev socializacije, ali brez njih. V prvem primeru imamo $v$ mislih izobraževanje, psihoterapijo, v drugem dejavni vpliv kulture in, denimo, religioznega življenja.

Še več, vprašanje povezanosti med nikoli zaključenim procesom nastajanja osebne in družbene identitete ter učljivostjo je nedvomno vprašanje, ki bi mu v današnjih okoliščinah lahko posverili več interdisciplinarne raziskovalne pozornosti.

1 Alexis.N. Leontiev (1975) Activité, conscience, personnalité, Moscou, Ed. Du Progres, 1984.

2 Perry, W.G.Forms of intellectual and ethical development in the college years. A scheme, New York, Holl, Reinhart anil Winston, 1970. 